\title{
Tectonic Shifts: Introduction
}

Christine Lorre

\section{(2) OpenEdition}

1 Journals

Electronic version

URL: https://journals.openedition.org/ces/7844

DOI: $10.4000 /$ ces. 7844

ISSN: 2534-6695

\section{Publisher}

SEPC (Société d'études des pays du Commonwealth)

\section{Printed version}

Date of publication: 1 September 2011

Number of pages: 7-10

ISSN: 2270-0633

\section{Electronic reference}

Christine Lorre, "Tectonic Shifts: Introduction", Commonwealth Essays and Studies [Online], 34.1 | 2011 Online since 16 November 2021, connection on 01 December 2021. URL: http:// journals.openedition.org/ces/7844 ; DOl: https://doi.org/10.4000/ces.7844

\section{(c) (i) (5)}

Commonwealth Essays and Studies is licensed under a Licence Creative Commons Attribution - Pas d'Utilisation Commerciale - Pas de Modification 4.0 International. 


\section{Introduction}

When Janet Frame sailed back to New Zealand from London in 1963 after spending seven years abroad, she met a young man named Albert, "a nuclear physicist travelling to take up a post in a New Zealand university where he hoped to concentrate on geophysics, volcanoes and earthquakes" (420). Albert becomes her companion throughout a voyage that started in sickness for Frame, describing and explaining to her "the formation of earth, water, sky," along with "violent earth movements, upheavals of fire and ashes" (421); and, Frame concludes, "enabl[ing] her to survive" (421). When the boat sails into Auckland harbor thirty-one days later, Frame is surprised to see members of the press seek her for interviews. She writes in "The Return," one of the final chapters of her three-volume autobiography:

I had not realised that in the seven years I had been absent, the publication overseas and in New Zealand of several books had built a reputation known as an overseas reputation and therefore valued apparently more than a reputation within New Zealand the reputation of excellent writers living in New Zealand was usually qualified by the phrase known within New Zealand only. (The growth of jet planes and the building of airports known as international resulted in the decline of overseas as an adjective of prestige and its replacement with international - an international reputation.) (422)

The first thing she does upon her return is to visit her dear friend and mentor Frank Sargeson in the northern suburb of Takapuna, noticing on the way all the changes in the urbanising landscape. Sargeson updates her on seven years of news about their mutual literary friends, concluding, "You may have an international reputation, [...] but do you know, Janet, you and I are passe'" (425).

The young physicist who can explain earthquakes to Frame enables her, through conversation, to take stock of her new understanding of her history as a mental patient, after consulting with doctors in London. The scene also announces the changes in the literary life of her native country that she encounters from the moment she sets foot there. Her rise to the status of a writer with an "overseas reputation," as opposed to the equivalent of a regional one ("known within New Zealand only"), is a sign among others of the emergence of New Zealand on the cultural world map as a national literature - by London indicators anyway. This is a far cry from 1945, which Frame remembers earlier in the autobiography as the year when she had her first mental breakdown, but also when two significant anthologies came out: $A$ Book of New Zealand Verse, edited by Allen Curnow, and Speaking for Ourselves, a book of short stories edited by Frank Sargeson. About the anthologies, Frame writes that "their force and variety gave me hope for my own writing while wakening in me an awareness of New Zealand as a place of writers who understood how I [felt]" (192). By 1963, Frame, through her own writing, could bridge the gap between her native place and the wider world. Yet more reshufflings in New Zealand's cultural geography, like earthquake aftershocks, were soon to take place. By the mid-1980s, when Frame was finishing her autobiography, New Zealand, which in the 1960s still beheld Britain as "Home," as its cultural centre, was developing stronger multilateral relations with other countries, in particular with the United States and Asian-Pacific 
countries. The mid-1980s is also when the terms "globalisation" and "global" started being used worldwide, replacing in turn the word "international" (Ashcroft et al 110).

The profound transformations evoked through Frame's story epitomise in their own way the types of changes that were then taking place across the world, and perhaps most acutely in what are now called postcolonial countries. Such cultural and literary upheavals caused by historical events of worldwide consequences are evoked in the metaphor of tectonic shifts used in this issue of Commonwealth Essays and Studies. The early 1960s was also the time when Marshall McLuhan in Canada published The Gutenberg Galaxy (1962) and coined the concept of "global village" (31) which has enjoyed renewed popularity in the Internet era. Globalisation, through which worldwide interrelationships have been made easier and more abundant, has led to the encounter of a number of multiple, heterogenous, and often contradictory discourses that together form various "zones of instability," to use Imre Szeman's phrase (3). How these zones are defined can vary considerably, both in space and time, as the several understandings of the term globalisation show. Widely used in conjunction with the process of internationalisation, the consequences of which have been increasingly visible since the mid-1980s, it is sometimes used more extensively, for example by some historians who talk of a "first globalisation" at the turn of the 19th and 20th centuries, or others who consider that worldwide interdependence mechanisms have been at work since the Great Discoveries (Douki and Minard 8). Yet others consider the term "globalisation" an altogether inadequate concept to understand complex forms of interconnectedness (see Cooper).

These questions were discussed by the participants in the sessions of the "New Literatures" workshop (entitled "Tectonic Plates: The Global and the Local") at the annual congress of the SAES in May 2011 in Paris. The eight essays gathered here study representations in postcolonial literature of deep local changes and transformations linked to the global history of the British Empire, or examine the related processes through which languages and consequently literature have been transformed.

Marta Dvorak's opening essay, "Inhabiting the EdgeS: Transtextuality and Subduction," uses the tectonic analogy to examine the concept of global dialogism and transculturalism in imperial contexts, relying on Bakhtin's notion of heteroglossia, to argue that the English language has often been expropriated by indigenous writers who happily work their way through the elasticity of the language. A sense of flux then prevails, rather than the hackneyed centre/edges paradigm, and a global literature, characterized by a mix of culture-specific and cross-cultural elements, emerges, which is often the expression of newly acquired linguistic freedom. A parallel to this (post)colonial situation is found in the way Modernists or late Modernists in England, the US, Ireland or the Caribbean worked common language into their literary writings, generating a stratification of language that bridges cultural divides. Dvorak observes a double process of erosion and construction going on in culture and language, that gives rise to fresh linguistic configurations.

Sneharika Roy's article, "Postcolonial Engagements with the Epics: Multiple and Movable Tectonic Plates," starts from the rich imagery of plate tectonics that Édouard Glissant favours - chaos-monde is an example - to render the multiple cultural interactions at work in the world. Critically returning to this paradigm, Roy examines a 
range of epics, from Walt Whitman's to Derek Walcott's, to focus on the un-Hegelian aspect of the postcolonial epic. Indeed, the collision of epochs and cultures they stage goes against a centripetal pull towards an imperial centre, so the epic stands not for a nation and its time, but is a participatory, relational form that reflects the interconnections among world cultures.

In "Modernism in Indian Poetry," Laetitia Zecchini also starts from tectonic shifts as an analogy for dialogic interaction to study the modern creativity that is found in the Indian poetry of the 1950s and 1960s, when cities like Bombay acted as fulcrums in the intense international circulation of cultural models. Zecchini also shows how translation further blurs pre-established boundaries, concepts and categories, and concurs with Glissant that globalisation is not about binary oppositions or uniformisation, but about defining one's relation to the whole surrounding world.

The title of Pascal Zinck's piece, "Bones of Contention," alludes to the conflict between the Darwinian and the creationist worldviews in Uzma Aslam Khan's novel, The Geometry of God. Zinck uses the tectonic analogy to analyse a situation of collision in which Islam's engagement with globalisation leads to radicalisation, and also, because the complex shifts in the earth's structure allow for more subtle and surprising movements and evolution, to examine the strategies used by the protagonists in their challenge to the rigid boundaries of an officially monolithic Pakistani identity.

The next two articles are devoted to Amitav Ghosh's Sea of Poppies, a novel set during the Opium Wars, which some analysts consider one of the first globalised armed conflicts (Chanda 176). In "Re-Mapping the Indian Ocean in Amitav Ghosh's Sea of Poppies," Sabine Lauret approaches the novel from the perspective of the diaspora of indentured labour - Indian coolies bound for Mauritius - and examines the multiple consequences of migration on identity, language and space, with imperial trade having a major impact on the Indian Ocean, and language being a crucial medium in the process of dislocation and relocation. Each language then may be seen as a continent subject to various types of friction for those who use it, or a terra incognita to explore for others.

Lise Guilhamon further demonstrates, in "Global Languages in the Time of the Opium Wars: The Lost Idioms of Amitav Ghosh's Sea of Poppies," how the process of deterritorialisation and subsequent relocation of languages at work in the novel leads to an adventure that implicitly goes against the received idea of a leveling, unifying effect of globalisation. Guilhamon thus analyses how Ghosh combines historical research and fiction to speculate and recreate the early global languages - and their various degrees of deterritorialised englishes - that in those days enabled sea-travellers from distant locations to communicate. In the process, Ghosh uses the poetic potential of language to contribute to the work of historical recreation, while conversely, historical research is mirrored in the fiction motif of the quest.

Salhia Ben-Messahel, in "Reconfiguring Australia's Literary Canon: Antipodean Cultural Tectonics," points out the analogy between the shifts of the Australian landmass and the slow evolution of the country towards a more open multicultural identity. She then takes stock of the evolution of Australian literature, starting from the momentum triggered by Patrick White in the early 1970s. The texts examined here are marked by a will to relate to the indigenous culture and to the land - in other 
words, to find ways of relocating oneself - that contrasts with the brutal collision of the colonial and subsequent periods. This recent trend also challenges the Hegelian view of Western civilisation being the end of history, as it brings indigeneity back to the centre, possibly making non-indigenous Australians exiles from within.

Héliane Ventura’s closing essay, "Genealogy and Geology: Of Metanarratives of Origin," examines the postcolonial return to origins through a selection of texts that have a predominant concern with geology. Ventura further demonstrates how, in two narratives by Alice Munro, the geological is underpinned by the mythological, and the genealogical is superimposed upon the geological, in a way that broadens the scope of Munro's regenerative claim on the past, through a process of self-discovery as geology.

These essays, taken together, tend to show that, in the various texts examined here, the "global" is overwhelmingly synonymous with new local configurations, not uniformisation or binary confrontation. The essays also reveal that these literary works, by blurring boundaries and loosening tight definitions, lead to a decentering of the European perspective, or, for that matter, any other form of monolithic perspective on history, language and culture. Erosion, subduction, collision, like the "upheavals of fire and ashes" that Frame's travelling companion explains to her, come to stand for the metamorphic transformations of literature.

Christine LORRE, guest editor

\section{Works Cited}

Ashcroft, Bill, Gareth Griffiths, and Helen Tiffin. Post-Colonial Studies: The Key Concepts. London: Routledge, 2000.

Chanda, Nayan. Bound Together: How Traders, Preachers, Adventurers, and Warriors Shaped Globalization. New Haven: Yale UP, 2007.

COOPER, Frederick. "What is the Concept of Globalization Good for? An African Historian's Perspective." African Affairs 100 (2001): 189-213.

FrAME, Janet. An Autobiography. New York: George Braziller, 1991.

SzEMAN, Imre. Zones of Instability: Literature, Postcolonialism, and the Nation. Baltimore: Johns Hopkins UP, 2003.

McLuHAn, Marshall. The Gutenberg Galaxy: The Making of Typographic Man. Toronto: U of Toronto P, 1962.

DoukI, Caroline, and Philippe MinarD. Introduction. "Histoire globale, histoires connectées : un changement d'échelle historiographique ?" Revue d'Histoire Moderne et Contemporaine 54.4Bis (2007): 7-21. 